\title{
Velella velella (Cnidaria: Hydrozoa) in the Bay of Ranobe, south-west Madagascar
}

\author{
MATtia GHILARDI* \\ CRIOBE, USR 3278 EPHE-CNRS-UPVD, University of Perpignan, Perpignan, France
}

Received 7 October 2018; Accepted 21 May 2019 Responsible Editor: Dhugal Lindsay

doi: $10.3800 /$ pbr. 14.206

\begin{abstract}
Velella velella widely occurs in the tropical and temperate oceans of the world and the number of mass strandings of colonies is increasing. Although its historical presence in the south-western Indian Ocean is known, recent observations are limited to Tanzania, Mauritius and South Africa. This is the first record of $V$. velella from Madagascar and the Mozambique Channel since 1964. Given the perceived increase in gelatinous zooplankton abundance, the lack of recent reports from this area highlights the need to monitor its presence to help coastal communities face the negative consequences of potential blooms.
\end{abstract}

Key words: Madagascar, pleustonic, Porpitidae, Velella velella, zooplankton

Velella velella Linnaeus, 1758, commonly known as the "by-the-wind sailor", is a pleustonic, open ocean species found globally in tropical and temperate oceans (Daniel 1976, Bieri 1977, McGrath 1985, Evans 1986, Mianzan \& Girola 1990, Flux 2008, Gul 2015, Fig. 1A). It is a holopelagic colonial anthoathecate hydrozoan belonging to the family Porpitidae. Numerous nominal species of Velella Lamarck,1801, have been described over the years, but all are now considered synonyms of a single species, $V$. velella (Calder 1988, Schuchert 2018).

This species feeds actively on diverse zooplanktonic prey including cladocerans, copepods and euphausiid larvae (Purcell et al. 2012, 2015, Zeman et al. 2018), and shows selection for fish eggs and larvae, making it a potential important predator and competitor of fish (Purcell et al. 2012). In addition, both $V$. velella colonies and medusae host symbiotic zooxanthellae that may provide supplementary nutrition. It is predated upon by a variety of oceanic vertebrate predators and specialised gastropods, especially by Glaucus sp. and Janthina sp. (Arai 2005, Lepoint et al. 2016, Phillips et al. 2017).

Velella velella is renowned for forming huge rafts at sea and for massive beach strandings that have been reported in many of the world's oceans (Evans 1986, Flux 2008, Purcell et al. 2015, Pires et al. 2018) and may deposit up to

*Corresponding author: Mattia Ghilardi; E-mail, mattia.ghilardi91@ gmail.com
$2.5 \mathrm{~kg}$ ash-free dry weight per metre of shoreline (Kemp 1986). This highlights its importance in open-ocean carbon cycling and in transport of pelagic production to landmasses (Purcell et al. 2012).

Despite the presence of 1,722 distinct records from the Indian Ocean (Fig. 1B) in the Ocean Biogeographic Information System (OBIS) and the Global Biodiversity Information Facility (GBIF), only about $2 \%$ of these $(n=37)$ have been reported in the last 50 years, including 21 from the Australian west coast. About $98 \%$ of sightings $(n=1,684)$ were reported before 1970 , all but 6 recorded during the International Indian Ocean Expedition (IIOE) conducted in 1959-1965 and reported in the World Ocean Database 2009 (Baranova et al. 2009), though other records may be scattered throughout the literature and await incorporation into biogeographic databases. No occurrences of the species have been documented in Madagascar and in the Mozambique Channel since 1964, when the American research ship Anton Bruun surveyed the area as part of the IIOE.

On $19^{\text {th }}$ August 2018, seven stranded colonies of $V$. velella were observed along the beach between the villages of

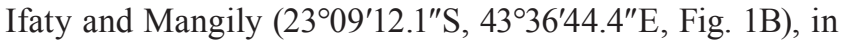
the Bay of Ranobe, south-west Madagascar, and one was observed in the same area on the $22^{\text {nd }}$. Only the latter was photographed (Fig. 2A-B) and measured using the software Fiji ImageJ (Schindelin et al. 2012), but it could not be collected. The size of the float was $46.2 \mathrm{~mm} \times 24.4 \mathrm{~mm}$. 

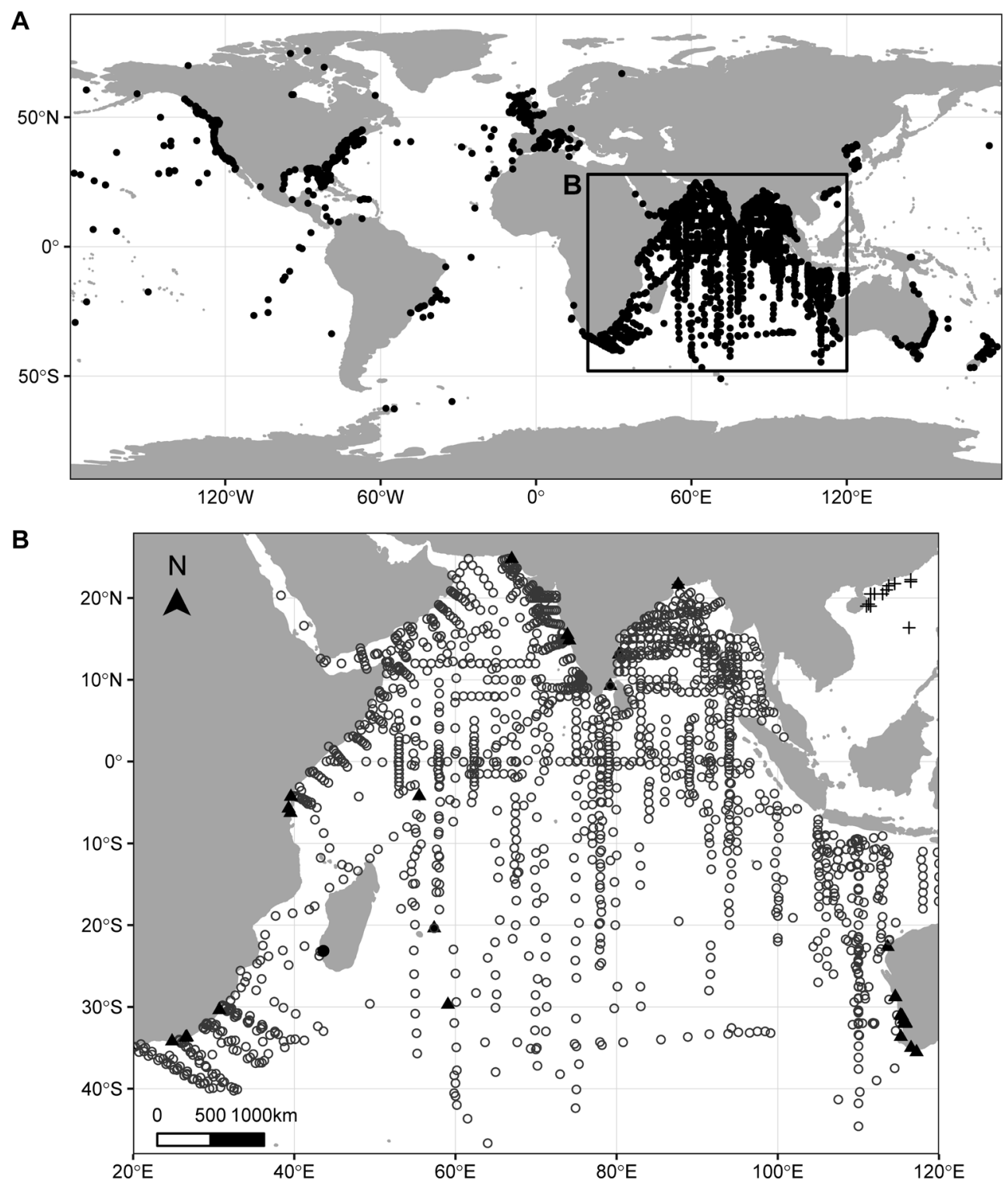

Fig. 1. A) Global distribution of Velella velella (based on data obtained from GBIF, https://doi.org/10.15468/dl.g1 spyf, and OBIS, https:// obis.org/taxon/117200). B) Records from the Indian Ocean over time: $(\bigcirc)$ observations recorded before 1970, $(\boldsymbol{\Delta})$ observations recorded in the last 50 years (1970-2019), (+) records for which the date has not been reported, (O) new observation from south-west Madagascar.

In addition, one colony of the hydroid Porpita porpita Linnaeus, 1758, was noticed floating in the lagoon close to the south pass $\left(23^{\circ} 08^{\prime} 54.1^{\prime \prime} \mathrm{S}, 43^{\circ} 34^{\prime} 34.3^{\prime \prime} \mathrm{E}\right)$ on the $22^{\text {nd }}$.

A comprehensive description of $V$. velella is provided by Schuchert (2010). Briefly, the floating colonial polyp stage is characterised by an oval, chitinous float, with an upright triangular sail, and exhibits the typical blue pigmentation of neustonic organisms due to the presence of astaxanthinproteins (Zagalsky \& Herring 1977). The sail is oblique to the long axis of the float and creates two mirror-symmetric forms. On the underside of the float, the colony has a central large gastrozooid encircled by a band of gonozooids that are also able to feed, and a peripheral ring of tentaclelike dactylozooids involved in prey capture. The asexual colony visible at surface releases numerous bell-shaped medusae that sink into deep waters and reproduce sexually. The larvae then develop into the well-known polymorphic colonies while ascending to the surface (Woltereck 1904).

All stranded specimens found in Ifaty were right-sailing (i.e. drift to the right in the downwind direction, Calder 1988, Fig. 2B). This form is less commonly observed than the left-sailing form, with most of the sightings occurring on the western shores of the southern hemisphere (Flux 2008, Araya \& Aliaga 2018). The presence of $V$. velella in the Bay of Ranobe may be the result of Southeast Trade Winds that blow every day during the austral winter.

After half a century since the last documented sighting of $V$. velella in Madagascar and in the Mozambique Channel, this recent observation confirms the presence of the 


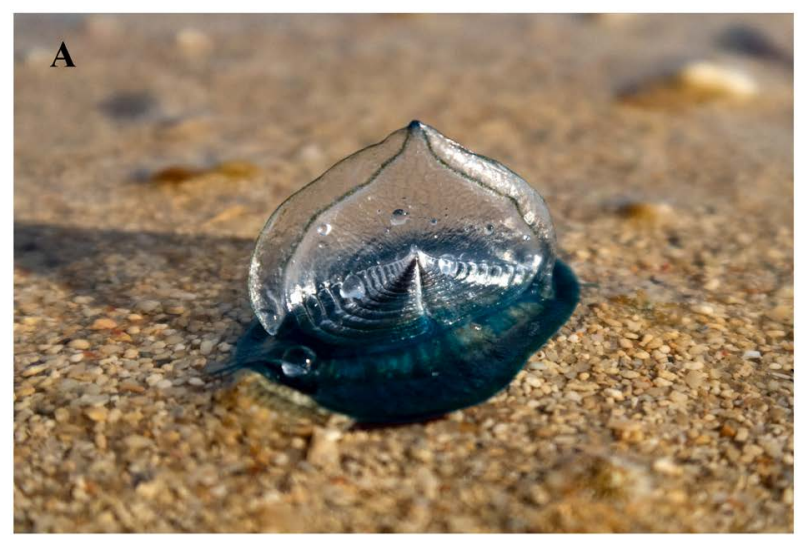

B

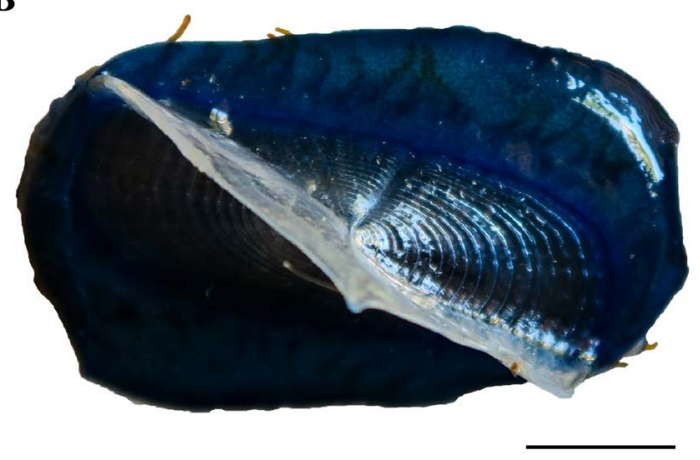

$10 \mathrm{~mm}$

Fig. 2. A) Velella velella stranded on Ifaty Beach, Madagascar. B) Top view of an R-form colony (right-sailing).

species in the area. Its abundance in tropical and temperate oceans and its importance as a predator and/or competitor of fish, suggest that the presence of this species in the Bay of Ranobe and along the south-west coast of Madagascar should be monitored. In fact, a mass occurrence may pose a risk to fish stocks already subject to high fishing pressure and to the thousands of people who rely on the sea as their only source of livelihood (Davies et al. 2009).

The lack of reports is not limited to this species, but more generally to gelatinous zooplankton, which are rarely documented along the African coasts. The perceived rise of gelatinous zooplankton in the world's oceans, although not yet clear (Condon et al. 2012), can have deleterious consequences for coastal communities (Richardson et al. 2009). The paucity of scientific data has led scientists to involve citizens for a more comprehensive monitoring of this phenomenon (e.g. Jellywatch.org). However, these initiatives are mostly restricted to North America or Europe, with sightings from the southern hemisphere mainly from Australia and New Zealand. The impacts of gelatinous zooplankton blooms may be greater along the African coasts, where the survival of millions of people is closely linked to the sea. It is therefore necessary that these populations, and the numerous organisations and diving centres that operate there, are more involved in these projects.

\section{Acknowledgements}

The observations were made during a period of volunteer work at Reef Doctor.org, a UK-based non-profit organisation that conducts conservation and social development in south-west Madagascar. The author is grateful to Reef Doctor.org for their hospitality and E. Fossile for providing helpful comments during manuscript preparation. I would also like to thank two anonymous reviewers for corrections and suggestions to the text.

\section{References}

Arai MN (2005) Predation on pelagic coelenterates: a review. J Mar Biol Assoc UK 85: 523-536.

Araya JF, Aliaga JA 2018 El Niño invaders: the occurrence of the by-the-wind sailor Velella velella (Linnaeus, 1758) in the southeastern Pacific. Spixiana 41(1): 132.

Baranova OK, O’Brien TD, Boyer TP, Smolyar IV (2009) Plankton data. Chapter 16 in Boyer TP, Antonov JI, Baranova OK, et al. 2009. World Ocean Database 2009. S. Levitus, Ed., NOAA Atlas NESDIS 66, U.S. Gov. Printing Office, Wash., D.C., 216 pp., DVDs.

Bieri R (1977) The ecological significance of seasonal occurrence and growth rate of Velella (Hydrozoa). Publ Seto Mar Biol Lab 24: 63-76.

Calder DR (1988) Shallow-water hydroids of Bermuda: the Athecatae. Royal Ontario Museum, Life Sciences Contributions 148, 1-107.

Condon RH, Duarte CM, Pitt KA, et al. (2013) Recurrent jellyfish blooms are a consequence of global oscillations. Proc Natl Acad Sci USA 110(3): 1000-1005.

Daniel R (1976) Chondrophora of the Indian Ocean. J Mar Biol Assoc India 18: 110-121.

Davies TE, Beanjara N, Tregenza T (2009) A socio-economic perspective on gear-based management in an artisanal fishery in South West Madagascar. Fish Manag Ecol 16: 279-289.

Evans F (1986) Velella velella (L.), the "by-the-wind-sailor", in the North Pacific Ocean in 1985. Mar Obs 56: 196-200.

Flux JEC (2008) First mass stranding of Velella velella in New Zealand. Mar Biodivers Rec 1: 1-2.

GBIF.org (2019) GBIF Occurrence Download. Available at: https://doi.org/10.15468/dl.g1spyf (accessed on 14 April 2019)

Gul S (2015) Velella velella (Hydrozoa) on the coast of Pakistan along the northern Arabian Sea. Taprobanica 7(1): 45-46.

Kemp PF (1986) Deposition of organic matter on a high-energy sand beach by a mass stranding of the cnidarian Velella velella (L.). Estuarine Coast Shelf Sci 23: 575-579.

Lepoint G, Bernard L, Gobert S, Michel LN (2016) Trophic interactions between two neustonic organisms: insights from Bayesian stable isotope data analysis tools. Belg J Zool 146: 123-133.

McGrath D (1985) The by-the-wind sailor Velella velella (L.) (Coelenterata: Hydrozoa) in Irish Waters 1976-1984. Ir Nat J 21: 479-484.

Mianzan HW, Girola CV (1990) The pleustonic coelenterates Physalia physalis (Linne, 1758), Velella velella (Linne, 1758) 
and Porpita umbella Muller, 1776 in southwestern Atlantic waters. Inv Mar CICIMAR 5: 97-98.

OBIS (2019) Distribution records of Velella (Lamarck, 1801) Available at: https://obis.org/taxon/117200 (accessed on 14 April 2019)

Phillips N, Eagling L, Harrod C, Reid N, Cappanera V, Houghton J (2017) Quacks snack on smacks: mallard ducks (Anas platyrhynchos) observed feeding on hydrozoans (Velella velella). Plankton Benthos Res 12(2): 143-144.

Pires RFT, Cordeiro N, Dubert J, Marraccini A, Relvas P, dos Santos A (2018) Untangling Velella velella (Cnidaria: Anthoathecatae) transport: a citizen science and oceanographic approach. Mar Ecol Prog Ser 591: 241-251.

Purcell JE, Clarkin E, Doyle TK (2012) Foods of Velella velella (Cnidaria: Hydrozoa) in algal rafts and its distribution in Irish seas. Hydrobiologia 690: 47-55.

Purcell JE, Milisenda G, Rizzo A, Carrion SA, Zampardi S, Airoldi S, Zagami G, Guglielmo L, Boero F, Doyle TK, Piraino S (2015) Digestion and predation rates of zooplankton by the pleustonic hydrozoan Velella velella and widespread blooms in 2013 and 2014. J Plankton Res 37: 1056-1067.

Richardson AJ, Bakun A, Hays GC, Gibbons MJ (2009) The jellyfish joyride: causes, consequences and management re- sponses to a more gelatinous future. Trends Ecol Evol 24(6): 312-322.

Schuchert P (2010) The European athecate hydroids and their medusae (Hydrozoa, Cnidaria): Capitata Part 2. Rev Suisse Zool 117: 337-555.

Schuchert P (2018) World Hydrozoa Database. Velella velella (Linnaeus, 1758). Available at: http://www.marinespecies.org/ hydrozoa/aphia.php? $\mathrm{p}=$ taxdetails\&id $=117832$ (accessed on 15 April 2019)

Schindelin J, Arganda-Carreras I, Frise E, et al. (2012) Fiji: an open-source platform for biological-image analysis, Nature methods 9(7): 676-682.

Woltereck R (1904) Ueber die Entwicklung der Velella aus einer in der tiefe vorkommonden Larvae. Zool Jb Suppl 7: 347-372.

Zagalsky PF, Herring PJ (1977) Studies of the blue astaxanthinproteins of Velella velella (Coelenterata: Chondrophora). Philos Trans R Soc Lond B 279(964): 289-326.

Zeman SM, Corrales-Ugalde M, Brodeur RD, Sutherland KR (2018) Trophic ecology of the neustonic cnidarian Velella velella in the northern California Current during an extensive bloom year: insights from gut contents and stable isotope analysis. Mar Biol 165: 150. 